\title{
Digital Payments: Impact Factors and Mass Adoption in Sub-Saharan Africa
}

\author{
Leigh Soutter, Kenzie Ferguson, and Michael Neubert
}

\author{
(6 Alas! how deeply painful is all payment! ") \\ Lord (George Gordon) Byron (1788-1824) \\ Poet and politician
}

\begin{abstract}
This study explores impact factors that affect the adoption of digital payment systems in sub-Saharan Africa. In this article, we investigate the impact factors that subject-matter experts consider most important to the success of FinTech payment models. The data and their responses are evaluated through the lens of Christensen's market-creation theory, which contends that the adoption of market-creating innovations by a mass swathe of heretofore non-consumers "pulls" framework conditions into place, including missing infrastructure and enabling regulation. Then, we compare the findings with the literature and three case studies of mobile money adoption in Kenya, South Africa, and Nigeria. This study addresses a gap in the literature regarding the payment and money transfer segment of FinTech innovations in Africa using a multiple case study methodology. We drew together information from multiple sources, including semi-structured interviews, archival data in the form of industry and regulatory reports, and observational field notes. Our findings suggest that enabling environments (Kenya) do jumpstart adoption and difficult frameworks (Nigeria) do evolve. This study will help FinTech innovators, academics, and policymakers to understand how technology and framework conditions impact payment business models in Africa.
\end{abstract}

\section{Introduction}

New FinTech firms, business models, and customer solutions are entering the sub-Saharan market at increasingly high rates (EY Global, 2019). But, is the explosion of innovation combined with the growing need for new financial services a match made in heaven? With 46 countries, sub-Saharan Africa is a patchwork quilt of framework conditions (Burns, 2018) with a track record of successes as well as false starts for products with good technical specifications (Christensen et al., 2019; FinMark Trust, 2017). The failures typically are pinned on shortcomings such as corruption, infrastructure, regulation, skills shortage, and over-expectations of the emerging middle class (Christensen et al., 2019; Simanis \& Duke, 2014; Sun, 2017).

Approximately $60 \%$ of adults in sub-Saharan Africa are unbanked (Demirgüç-Kunt et al., 2018; Medina et al., 2017). These non-consumers of formal financial services deal mainly in cash despite academics, development organizations, and governments urging for their participation in the formal economy because financial inclusion is foundational for poverty reduction and economic growth (Demirgüç-Kunt et al., 2018). Christensen, Ojomo, and Dillon (2019) state that, in subSaharan Africa, there are great opportunities for businesses that truly understand and enable non-consumers at low margins, and the engagement of the authors sparks institutional evolution and instigates long-term prosperity where the opportunities are adopted.

The purpose of this multiple-case-study is to explore subject-matter experts' perceptions of how demand, technology, and framework conditions impact the success of digital money transfer or payment business models in Africa. The methodology combines multiple sources of evidence, including semi-structured interviews, archival data in the form of industry reports, and observational field notes. Data triangulation is conducted to validate the study's data analysis and findings. 


\section{Digital Payments: Impact Factors and Mass Adoption in Sub-Saharan Africa}

Leigh Soutter, Kenzie Ferguson, and Michael Neubert

This study follows a call for research from Gomber, Koch, and Siering (2017), who state that FinTech innovations are based on easy usage and lower cost from the customer perspective and regulation and technological innovations called for a further verification and extension of their findings in other jurisdictions and industries. This study tries to close this gap in the literature by exploring how the dynamic tension between consumers, technologies, and institutions impacts the success of digital payment systems in sub-Saharan Africa.

The article is structured into five parts. The first part covers a brief review of the current literature, introduces the theoretical framework, and describes the case studies. The second part covers the research methodology. The third part presents the findings. The fourth part discusses the findings and compares them to findings of other studies. The fifth part is the conclusion.

\section{Literature Review}

\section{Africa's FinTech sector}

In sub-Saharan Africa, approximately $60 \%$ of the adult population does not use formal financial services (Demirgüç-Kunt et al., 2018). Cash is the predominant method of value exchange, as it is easy to use, widely accepted, and ingrained to a user's psyche as having value (Weichert, 2017). Moreover, there are obstacles to banking such as distance to bank outlets (and risks when carrying cash), lack of trust, daunting paperwork, and overwhelming identity and documentation requirements (Realini \& Mehta, 2015).

The main force driving financial inclusion in sub-Saharan Africa is mobile money (Demirgüç-Kunt et al., 2018). Where it has been successful, the market has grown rapidly, for example, increasing from 75 million accounts in 2012 to almost 340 million in 2017 (GSMA, 2018a). In a recent International Monetary Fund (IMF) publication, Sy and co-authors (2019) compare mobile money uptake in 17 economies in sub-Saharan Africa, and their report shows mobile money rapidly surpassing traditional banking for the region. According to the authors, "FinTech is not only helping improve financial inclusion in the region, but it also serves as a catalyst for the emergence of innovations in other sectors, such as agriculture and infrastructure, which promotes economic growth and development." (Sy et al., 2019). However, relevant to the studies examined here, among the 17 economies examined by Sy and co-authors (2019), Kenya ranked second but Nigeria and South Africa ranked near the bottom in mobile money transactions.
Currently, over 260 companies operate in the FinTech sector in sub-Saharan Africa (EY, 2019). The payments segment and the services that enable it to "dominate" the space (EY, 2019). These technologies include mobile money (i.e., making financial payments with mobile devices), electronic money (i.e., storing money in an electronic account), peer-to-peer payments (i.e., financial payments from one person to another through an intermediary, such as a payment app), digital currency (i.e., a currency that is only available in digital form), and blockchain (i.e., a distributed ledger technology), but mobile money is the primary FinTech solution used in sub-Saharan Africa (Sy et al., 2019). EY (2019) projects that payment solutions will dominate the SSA FinTech for the foreseeable future, at least until the need for financial inclusion is sufficiently addressed.

\section{Mobile money business models}

Chironga, De Grandis, and Zouaoui (2017) identify five business model archetypes for African mobile money providers (Table 1), according to which segments of the value chain they cover:

1. MNO-dominant in which the mobile network operator (MNO) is responsible for most steps of the value chain

2. MNO-led partnerships in which a banking partner supports the MNO with products beyond payments

3. Bank-led partnerships in which an MNO provides online capability

4. Bank models in which the bank provides the digital services

\section{FinTech solutions}

Chironga and co-authors (2017) show that MNOs have dominated the mobile money industry in Africa for the past 10 years. They attribute the success of MNOs to three key factors: 1) a large customer base with strong market concentration (i.e., mobile phone penetration compared to banking penetration); 2) a superior client experience; and 3) the ubiquity of the MNOs' local agent distribution networks (e.g., compared to ATMs). The cash distribution agents - which provide local cash-incash-out (CICO) services, register accounts and, for mobile phone providers, top up prepaid phone accounts are the primary way to convert money (e.g., a shoebox of cash) into a digital asset (e.g., e-money in a mobile money account), and they are key to the growth of the mobile money industry (Juma \& Wasunna, 2018; Realini \& Mehta, 2015). 


\title{
Digital Payments: Impact Factors and Mass Adoption in Sub-Saharan Africa
}

\author{
Leigh Soutter, Kenzie Ferguson, and Michael Neubert
}

Table 1. Mobile money business model archetypes (adapted from Chironga et al., 2017)

\begin{tabular}{lccccc} 
& \multicolumn{5}{c}{ Value Chain Element } \\
\cline { 2 - 6 } Archetype & $\begin{array}{c}\text { Deposit } \\
\text { Holder }\end{array}$ & $\begin{array}{c}\text { E-Money } \\
\text { Issuer }\end{array}$ & $\begin{array}{c}\text { Payment } \\
\text { Platform }\end{array}$ & Agents & $\begin{array}{c}\text { Telecom } \\
\text { Channel }\end{array}$ \\
\hline MNO-dominant & Bank & Telco & Telco & Telco & Telco \\
\hline MNO-led & Bank & Bank/ Telco & Telco & Telco & Telco \\
\hline Bank-led & Bank & Bank & Bank & Bank & Bank / Telco \\
\hline Bank-dominant & Bank & Bank & Bank & Bank & Telco \\
\hline Third party & Bank & FinTech & FinTech & FinTech & Telco \\
\hline
\end{tabular}

\section{Enabling environments for mobile money}

Burns (2018) found that the best results of entrepreneurship and experimentation in financial technology do not necessarily occur in nations that devote the most resources to financial inclusion. "Instead, the greatest success stories have occurred in nations where the government has restricted itself to merely creating an 'enabling' environment for entrepreneurs" (Burns, 2018). His study of enabling environments considered factors such as population, economic freedom, whether the country has a dominant telecom provider, regulatory approach, and the number of mobile money accounts. His findings, as summarized in Table 2, show that the countries with "enabling" FinTech regulations have a substantially more mobile money accounts compared to the four "non-enabling" countries.

Another influential factor is the depth of banking and its innovativeness, such as for fundraising innovations (Neubert, 2019). According to Chironga and co-authors (2017), where banking is strong and there are numerous bank outlets (e.g., South Africa), the uptake of mobile money is relatively slow. Their research shows that the maturity levels of mobile money operators are highest where the financial services market is fragmented and where regulators have allowed telecoms to compete (e.g., Kenya and Tanzania). Sleeping giants (e.g., Nigeria) have both a reasonably well-developed banking system and regulations that constrain mobile money operators (Chironga et al., 2017), as the slow and stony development of Paga, a Nigerian FinTech payment solution with today 13 million customers and more than 21,000 agencies, and licensed by the Central Bank of Nigeria, shows (Lepoutre \& Oguntoye, 2018).
Sy and co-authors. (2019) describe enabling conditions for network effects, "Policymakers should look beyond the potential benefits of FinTech in just the financial sector to consider the possible impact on employment and productivity, the digital economy, and more broadly, the scope for much needed structural transformation." Thus, FinTech and especially financial inclusion might be considered as drivers for economic growth and prosperity (Naboulsi \& Neubert, 2018).

In his seminal work, The Innovator's Dilemma: When New Technologies Cause Great Firms to Fail, Clayton Christensen (1997) describes how established companies lose market leadership to new disruptive innovations that may sacrifice the performance that current customers expect but offer a different package of attributes that can open up entirely new markets. The focus shifts to emerging economies in Prosperity Paradox: How Innovation Can Lift Nations Out of Poverty by Christensen and co-authors (2019), who describe disruptive innovations that solve basic problems at low margins for wide swathes of heretofore non-consumers. Their framework for business models in this market includes:

- Non-Consumption: Rather than target customers of existing products, the business aims for would-be consumers who are unable to purchase the existing product because it is too expensive or difficult to use for large segments of the population.

- Enabling Technologies: The business generally involves an enabling technology that improves performance at low cost or provides a competitive edge. 


\section{Digital Payments: Impact Factors and Mass Adoption in Sub-Saharan Africa}

\section{Leigh Soutter, Kenzie Ferguson, and Michael Neubert}

Table 2. Enabling and non-enabling environments for mobile money in Africa (2007 to 2017) (adapted from Burns, 2018)

\begin{tabular}{|c|c|c|c|c|c|}
\hline \multirow[b]{2}{*}{ Country } & \multicolumn{5}{|c|}{ Characteristic } \\
\hline & Enabling & $\begin{array}{c}\text { Dominant } \\
\text { Telecom }\end{array}$ & $\begin{array}{l}\text { Moderate / High } \\
\text { Population } \\
\text { Density }\end{array}$ & $\begin{array}{l}\text { Moderate } \\
\text { Economic } \\
\text { Freedom }\end{array}$ & $\begin{array}{l}\text { Mobile Money } \\
\text { Accounts } \\
\text { (millions) }\end{array}$ \\
\hline Nigeria & No & Yes & Yes & Yes & $<0.9 \quad(0.5 \%)$ \\
\hline Botswana & No & Yes & Yes & No & $<0.3 \quad(12 \%)$ \\
\hline South Africa & No & Yes & Yes & Yes & $<0.5 \quad(0.01 \%)$ \\
\hline Ghana & No & Yes & Yes & Yes & $<2.0 \quad(7 \%)$ \\
\hline Kenya & Yes & Yes & Yes & Yes & $30.00 \quad(80 \%)$ \\
\hline Uganda & Yes & No & Yes & Yes & $18.50 \quad(60 \%)$ \\
\hline Tanzania & Yes & No & No & Yes & $41.40 \quad(80 \%)$ \\
\hline Zimbabwe & Yes & No & No & No & 7.35 (66\%) \\
\hline Somalia & Yes & No & No & No & $7.25 \quad(66 \%)$ \\
\hline
\end{tabular}

- Emergent Strategies: The innovator adopts a flexible strategy and learns from their would-be customers to refine products and pursue markets that are not yet defined.

- New Value Networks: Businesses may rethink and radically change traditional inputs, processes, and distribution strategies to make products that are useful and affordable to the heretofore non-consumers.

- Pull Strategy of Development: Non-consumers pull the innovation into their lives, and the job creation, tax flow, and so on "pull" necessary infrastructure and institutions into society.

According to their theory, successful innovators in emerging markets may need to navigate politically and economically unstable environments, without the benefit of ideal institutional guidance and regulation. They may need to reconfigure their value networks to include consumer education and missing fundamental elements that are readily available in a developed economy, including infrastructure, product inputs, peripheral functions, and distribution channels (Christensen et al., 2019; Simanis \& Duke, 2014; Sun,
2017). Christensen and co-authors (2019) claim that, while long-term prosperity ultimately requires good governance, market-creating innovations can ignite the economic engine of a country, and the new markets and their network effects pull the required infrastructure and institutions into place.

Examples of FinTech markets in sub-Saharan Africa Our case studies focus on FinTech journeys with respect to mobile money for Kenya, South Africa, and Nigeria (see Table 3), which are widely regarded as the key technology hubs in sub-Saharan Africa (EY Global, 2019) and accounted for more than two-thirds of total venture funding (\$580M USD) in 2017 (GSMA, 2018b).

\section{Kenya}

Kenya is the flagship economy of East Africa, the epicentre of mobile money in Africa, and home to mobile money innovator M-Pesa (safaricom.co.ke). Telecom Safaricom launched M-Pesa in Kenya in 2007 when $30 \%$ of the population had mobile phones, fewer than $25 \%$ of Kenyans had bank accounts, and there were only seven ATMs per 100,000 people (Table 3) (Naboulsi \& Neubert, 2018). 


\section{Digital Payments: Impact Factors and Mass Adoption in Sub-Saharan Africa}

Leigh Soutter, Kenzie Ferguson, and Michael Neubert

Table 3. Mobile money adoption framework statistics for Kenya, South Africa, and Nigeria

\begin{tabular}{|c|c|c|c|}
\hline \multirow[b]{2}{*}{ Characteristic } & \multicolumn{3}{|c|}{ Country } \\
\hline & Kenya & South Africa & Nigeria \\
\hline Population (millions) ${ }^{1}$ & 50 million (2017) & 57 million (2017) & 191 million (2017) \\
\hline Informal economy (\% of GDP) ${ }^{2}$ & $33 \%(2016)$ & $25 \%(2016)$ & $65 \%(2016)$ \\
\hline ATMs per 100,000 people $^{1}$ & $\begin{array}{l}7(2007) \\
9(2016)\end{array}$ & $\begin{array}{l}30(2007) \\
68(2017)\end{array}$ & $\begin{array}{c}4(2007) \\
16(2017)\end{array}$ \\
\hline Households with a personal computer ${ }^{1}$ & $0.5 \%(2000)$ & $14.8 \%(2007)$ & $5.1 \%(2007)$ \\
\hline Households with a telephone ${ }^{1}$ & $1.2 \%(2007)$ & $9.8 \%(2007)$ & $1.0 \%(2007)$ \\
\hline SIM penetration $^{3}$ & $\begin{array}{l}30 \%(2007) \\
93 \%(2018)\end{array}$ & $\begin{array}{c}85 \%(2007) \\
172 \%(2018)\end{array}$ & $\begin{array}{l}28 \%(2007) \\
79 \%(2018)\end{array}$ \\
\hline Prepaid mobile accounts (\% of connections) ${ }^{3}$ & $97 \%(2018)$ & $89 \%(2018)$ & $96 \%(2018)$ \\
\hline Internet penetration 4 & $46 \%(2017)$ & $54 \%(2017)$ & $48 \%(2017)$ \\
\hline Facebook penetration ${ }^{4}$ & $39 \%(2017)$ & $73 \%(2017)$ & $20 \%(2017)$ \\
\hline Technological readiness (scale $0-7)^{1,4}$ & $3.7(2017)$ & $4.6(2017)$ & $3.0(2017)$ \\
\hline Mo Ibrahim governance index (scale $0-100)^{5}$ & $60(2017)$ & $68(2017)$ & $48(2017)$ \\
\hline Moderate economic freedom ${ }^{6}$ & Yes (2007-2016) & Yes (2007-2016) & Yes (2007-2016) \\
\hline Mobile money business model ${ }^{7}$ & MNO-dominant & Bank-dominant & Third party \\
\hline Enabling regulation ${ }^{6}$ & Yes (2007-2016) & No (2007-2016) & No (2007-2016) \\
\hline Mobile money penetration ${ }^{6}$ & $80.00 \%(2016)$ & $0.01 \%(2016)$ & $0.50 \%(2016)$ \\
\hline Mobile money transactions per person ${ }^{1}$ & $53(2016)$ & $0.1(2016)$ & $0.5(2016)$ \\
\hline
\end{tabular}

Sources:

1. World Bank (2019a)

2. Medina et al. (2017) for IMF

3. GSMA (2019)

4. Sy et al. (2019) for IMF

5. IIAG (2018)

6. Burns (2018)

7. Chironga et al. (2017) 


\title{
Digital Payments: Impact Factors and Mass Adoption in Sub-Saharan Africa
}

\author{
Leigh Soutter, Kenzie Ferguson, and Michael Neubert
}

Institutionally, M-PESA was formed in a de facto sandbox. When it launched, mobile money technology had champions in government who saw it as a way to move informal money "out from under the mattress" (Sun, 2017), and neither the communications commission nor the central bank had authority over the service at its inception (AFI, 2010). After accumulating over five million customers in just two years, a formal risk assessment was performed and M-Pesa was officially allowed to operate under non-bank status (AFI, 2010).

M-PESA currently has 15 million registered users (GSMA, 2018a), 40,000 mobile money agents (Safaricom, 2019), and a thriving ecosystem around it (e.g., MShwari for loans, Lipa for merchants, M-Tiba for healthcare, and M-Kopa for pay-as-you-go solar). Regulators in Kenya have since taken a "test and learn" approach to regulation of FinTech innovations and formalized sandboxes. Despite significant differences in regulation, M-PESA started to expand quite early to foreign markets, first within sub-Saharan Africa and later into Asia and Eastern Europe, similar to other born-global firms (Neubert, 2017, 2018).

\section{South Africa}

In South Africa, approximately $80 \%$ of the population has a formal bank account, and the regulatory environment strongly favours banks (Table 3). Still, South Africans mainly deal in cash, and informal merchants are reluctant to use non-cash methods.

Mobile money has not "taken off" in South Africa. A first wave of mobile money effectively ended in 2016 when competitors M-Pesa (vodacom.co.za) and MTN Mobile Money (mtn.com) discontinued offering solutions there. FinMark Trust (2017) autopsied the situation and discovered that, in South Africa, mobile money was plagued by regulatory issues, poorly performing technology, and difficulties with the local agent cash-in-cashout services.

While the Finmark Trust study (2017) concludes that mobile money can be successful in South Africa with more favourable regulation and new business models, it has not happened yet. However, there appears to be renewed interest for the service in South Africa now, including, for example, public news and press releases for MTN Mobile Money reveal plans to relaunch in South Africa (e.g., plus new interoperability and a Pan-African partnership).

\section{Nigeria}

Nigeria has the largest population and largest GDP in Africa, and while oil dominates Nigeria's economy, almost $50 \%$ of the population lives in below the international poverty line of $\$ 1.90$ per day (World Bank, 2019b). Despite mobile phone penetration greater than $75 \%$ (Table 3), mobile money is yet to be successful in Nigeria.

The Central Bank of Nigeria (CBN) published its first regulatory framework for mobile payments in 2009 to create an "enabling" environment that promotes financial inclusion. By 2015, there were more than 20 licensed mobile money operators (MMOs) competing in a fragmented environment. They siloed their solutions, failed to simplify the cash-to-mobile money handoff, could not scale or lacked sufficient capital or industry knowledge to be successful (USAID, 2018). The central bank authored new regulation to correct the situation (CNB, 2015a, 2015b), and despite mobile network operators (MNOs) tending to be sufficiently capitalized for this role, the CBN would not license MNOs for mobile money services, apparently owing to anti-monopoly concerns (USAID, 2018). By 2017, mobile money had stalled in Nigeria - there was less than one transaction per adult per year compared to 52 transactions in Kenya (IMF, 2019). However, in 2018, Nigeria opened licensing for mobile money operation to MNOs (CBN, 2018a) and subsequently released additional guidance (CBN, 2018b) for a shared agent network to promote financial inclusion. Within one month of the announcements, the telecom MTN announced plans to obtain licensing and start their mobile money solution in Nigeria (Quartz Africa, 2018).

\section{Research Methodology}

A qualitative multiple-case study research design is used to answer the exploratory research questions (Yin, 2017). This research design allows for more flexibility using different sources of evidence, offers the possibility of a cross-case analysis, and can go deeper and in greater detail than a quantitative assessment (Yin, 2017). This research methodology is aligned with the purpose of this study, because we want to explore the perceptions of the interviewed experts (see Table 4) based on their experience in the digital payment system sector in sub-Saharan Africa, including all the complexities and subtleties of innovative technologies in developing markets. 


\section{Digital Payments: Impact Factors and Mass Adoption in Sub-Saharan Africa}

\section{Leigh Soutter, Kenzie Ferguson, and Michael Neubert}

Table 4. Professional experience of interviewed experts in the African financial service industry

\begin{tabular}{cllll} 
Expert & Education & Professional Level & $\begin{array}{l}\text { Professional } \\
\text { Experience in Africa }\end{array}$ & $\begin{array}{l}\text { Professional Experience in } \\
\text { Finance or Technology? }\end{array}$ \\
\hline 1 & Master & Entrepreneur / Owner & Direct & Yes \\
\hline 2 & Master & Entrepreneur / Owner & Direct & Yes \\
\hline 3 & Master & Senior Manager & Direct & Yes \\
\hline 5 & Master & Senior Manager & Direct & Yes \\
\hline 6 & Doctorate & Entrepreneur / Owner & Direct & Yes \\
\hline 7 & Master & Senior Manager & Direct & Yes \\
\hline 8 & Master & Senior Manager & Direct & Yes \\
\hline 9 & Master & Entrepreneur / Owner & Direct & Yes \\
\hline 10 & Master & Entrepreneur / Owner & Direct & Yes \\
\hline 11 & Doctorate & Senior Manager & Direct & Yes \\
\hline 12 & Master & Entrepreneur / Owner & Direct & Yes \\
\hline
\end{tabular}

In this study, we used a purposive sampling strategy of 12 subject-matter experts with strong theoretical, entrepreneurial, and financial backgrounds in markets in sub-Saharan Africa (Yin, 2017). The sample includes experts with professional knowledge about digital payment systems in sub-Saharan Africa. They all hold degrees at the master's level or higher with multiple years of experience as senior managers and entrepreneurs/owners in the financial or technology sector. Additional sources of evidence include interviews, case studies based on regulatory institution data, and industry data.

This multiple-case study uses semi-structured, qualitative, in-depth interviews to collect the perceptions of the experts about the users of digital currencies in subSaharan Africa. The questionnaire contains several open questions to answer each of the research questions. Data collection took place in Paris in November 2018 using an online questionnaire. The interviews lasted between 32-46 minutes.
The following three research questions are addressed in this study:

1. How do subject-matter experts perceive the influence and the impact of customer demand on the success of money transfer or payment business models in Africa?

2. What are the perceptions of subject-matter experts about the main technologies to develop new business models for money transfer or payment systems in Africa?

3. What are the perceptions of subject-matter experts about the required framework conditions and success factors to develop new business models for money transfer or payment systems successfully in Africa?

The data analysis used a standardized process starting from the analysis of industry reports, market reports, 


\section{Digital Payments: Impact Factors and Mass Adoption in Sub-Saharan Africa}

Leigh Soutter, Kenzie Ferguson, and Michael Neubert

and regulatory documents, followed by the analysis of each interview, a cross-case analysis to compare the similarities and differences, and a triangulation with other sources of evidence to develop themes, which answer the research questions (Yin, 2017). To facilitate the complex data collection and analysis, the analytical software NVivo was used to analyze the unstructured data from different sources of evidence with the goal to produce robust and qualitative research findings, which might be transferred to other settings.

\section{Findings}

Customer demand will grow as awareness of the benefits of digital money transfer spreads

All subject-matter experts in this study express that customer demand is critical to the success of the money transfer and payment business models. Most say it is a "precondition" to the success of the business models; however, the answers also convey that increasing awareness is needed to drive demand.

Experts mention that success stories from "neighbouring communities" about products "designed to meet the exact needs of customers" and "competition among such services will stimulate interest and fuel demand". Five in particular note that rural areas and villages will require significant effort. The answers to the first research question have an element of educating consumers on the technology and the benefits that digital money transfer models offer. Most respondents see the target market coming from the informal economy; they mention "unbanked people" and their "unmet needs in the financial sector" being the "large segment of potential clients to target".

Table 5 lists key responses to this question about customer demand and telling quotes from responses from other questions that confirm that the experts see the unbanked informal economy to be the main audience for the new business models.

The answer to the first research question, "How do subject-matter experts perceive the influence and the impact of customer demand on the success of money transfer or payment business models in Africa?", is that customer demand is necessary for success but needs to be stimulated. In other words, demand will grow as the new businesses solve customer problems and awareness of their benefits spreads, which is consistent with findings by Ferguson and Neubert (2019). The expert responses suggest the primary customers will be largely unbanked, and this is supported by the record of mo- bile money in Kenya (i.e., in the current case study) and growth of mobile money elsewhere in Africa (Chironga et al., 2017; Demirgüç-Kunt et al., 2018; GSMA, 2018a). In terms of the theoretical framework, this appears to be a classic non-consumption opportunity as described by Christensen and co-authors (2019), who claim that much wealth can be created by efficiently solving "jobs to be done" for bottom-of-the-pyramid customers.

\section{Functional and affordable mobile platforms are central} to new business models for digital payment systems in sub-Saharan Africa

Table 6 lists key responses to the second research question. The subject-matter experts unanimously project that new business models for money transfer and payment systems in sub-Saharan Africa will hinge on affordable mobile platforms. Throughout the answers is a fundamental concern for penetration, stability, and transaction speed of connections (cellular, broadband, or Wi-Fi). Two suggest SMS text messaging in particular to perform transfers, presumably due to concerns for lower cost and connection stability.

Six respondents mention security features such as voice, fingerprint, and face recognition to simplify use and offer security, tools such as near field communication (NFC) and encryption, and other risk control measures including insurance and dispute-resolution technologies. Several experts explicitly or implicitly mention ancillary programs so customers "learn [how to work the technology] using applications." Big data and analytics are suggested by three experts for "monitoring of new services" and access to other products such as credit and financing.

New digital money transfer and payment systems in subSaharan Africa need to de-risk, lower the cost, and simplify the sending and managing of money

Lowering costs and simplifying the user experience is an important theme within seven responses. The subject-matter experts mention applications for "low-cost" or "free" money transfers and eliminating expensive intermediaries. Three experts call explicitly for direct peer-to-peer transfers, peer-to-peer lending, and, to a lesser extent, crowdfunding. Others call for tools that aid "overall money management including planning and budgeting".

Four respondents specify blockchain (which also enables peer-to-peer transfers) as an underlying technology and four mention cryptocurrency, noting price stability in international transfers (relative to inflation), reduction in exchange charges, enhanced security and 


\title{
Digital Payments: Impact Factors and Mass Adoption in Sub-Saharan Africa
}

\author{
Leigh Soutter, Kenzie Ferguson, and Michael Neubert
}

Table 5. Selected quotations from interviewees in response to questions about customer demand (Research Question 1) and deeper questioning (i.e., about the informal economy)

$$
\begin{aligned}
& \text { Category } \\
& \text { Customer demand } \\
& \text { - "Customer demand is a precondition for the development of business models" } \\
& \text { - "Customer demand will shape the business models in Africa" } \\
& \text { "Convenience and low cost will drive demand; demand will drive use; use will drive network } \\
& \text { "Continuous demand (for MPesa) obliged regulators to implement new regulations and } \\
& \text { frameworks" } \\
& \text { "Customer demand is the reason of the success of money transfer business in Africa" } \\
& \text { " } \text { "As soon as they see success stories from their neighbouring communities, they may also show } \\
& \text { "Due to the education level, it may take quite some time until the people from Africa adapt to } \\
& \text { these developments" } \\
& \text { "Competition among such services may also increase, and rural villages may develop in a better } \\
& \text { way" "The biggest advantage that MPTS (mobile payment and transfer system) models had over } \\
& \text { traditional channels is that they were designed to meet the exact need of customers, should they } \\
& \text { be related to a specific service (money transfer), availability in a specific country, or reaching } \\
& \text { customers where others can't (rural areas)" }
\end{aligned}
$$

Informal economy

- "In the African environment, the level of unbanked people and the number of unmet needs in the financial sector are probably very appealing to new MPTS (mobile payment and transfer system) models as they would have a large segment of potential clients to target which are not being currently served"

- "New technology that enables more access to credit and financing; especially where it enables participants from the informal sector"

- "Many of these new technologies hold promise of bringing money that has been sequestered in informal businesses to the larger economy, democratizing access to capital, and increasing the user base in general"

the potential to shorten transfer times. Although one respondent claims blockchain and distributed ledger technology have great potential to "overhaul" value transfer systems, others point to limitations including unreliable Internet and regulatory concerns that make their widespread use impractical in present-day subSaharan Africa.

The answers to the second research question, "What are the perceptions of subject-matter experts about the main technologies to develop new business models for money transfer or payment systems in Africa?", show that the respondents believe the current growth of digital payment systems in sub-Saharan Africa will facilitate the success of innovative technologies. We also repor- ted this finding in our previous study (Ferguson \& Neubert, 2019). Consistent with the literature (e.g., EY, 2019; Sy et al., 2019), the expert responses suggest that the main focus for the near future is innovation that makes mobile money transfers and payments platforms functional, accessible, easy to use, and affordable. While the experts say cryptocurrencies and blockchainbased platforms could be used "under the hood" to improve mobile money models, not all are convinced that they will replace traditional digital payment systems. Our experts' call for an abundance of supporting features to aid learning and adoption may not be supported by theory, as Christensen and co-authors (2019) caution that a parsimonious approach to product development for bottom-of-the-pyramid opportunities may 


\title{
Digital Payments: Impact Factors and Mass Adoption in Sub-Saharan Africa
}

\author{
Leigh Soutter, Kenzie Ferguson, and Michael Neubert
}

Table 6. Selected quotations from interviewees in response to questions about technologies (Research Question 2)

\begin{tabular}{l} 
Qutegory \\
\hline Technology \\
- "A money transfer system needs to be cheaper to succeed in Africa" \\
- "Other software and online tools for aiding overall money management including planning and \\
- " "International and domestic money transfers via SMS" \\
- "Shops like Western Union that enable transfer of funds via cash" \\
- "Peer-to-peer lending is one of the top technologies to develop new business models in Africa for \\
- "Money transfers" \\
- "Mig data and cloud services to help storage, analysis and monitoring of new services" \\
- "Big data + AI + ML + IoT - New technology that enables more access to credit and financing; \\
- "Dispute revolution: Convenient, low-cost, efficient, and effective dispute resolution" \\
- "Insurance: Protection against fraud and identity theft or other cyberpiracy"
\end{tabular}

be required. Thus, businesses need to learn about their customers and focus on the features they can and will use. In the case of Kenya, M-Pesa began with low prices and a simple time-saving product. It was only after they reached a critical mass that the M-Pesa ecosystem began to develop.

Technology infrastructure, customers, and favourable regulation are required framework conditions for successful new money transfer and digital payment system models in sub-Saharan Africa

The respondents generally agree that three key framework conditions are critical to developing new business models for money transfer and payment systems in subSaharan Africa.

Ten subject-matter experts mention the extent and quality of technology infrastructure as a framework condition necessary for the success of the new business models. They especially focus on "reasonably priced, secure internet connectivity" and the ability "to connect with rural areas." Nine respondents also mention penetration of Internet / mobile phone users (i.e., potential customers). Nine experts express concern that heavy-handed regulation will hinder FinTech entrepreneurs and slow adoption. Several point to Kenya's wait-and-monitor approach and sandbox licensing as a success. One expert mentioned RegTech innovations (i.e., regulatory technology: the use of technology to meet compliance requirements) "to enable a better understanding and monitoring of the new mobile ecosystem".

Throughout the responses is an eye toward cooperation and collaborations that facilitate consumer adoption. For example, one expert mentions payment incentives to achieve "network effects" with government and employer payments (inbound) and discounts on taxes, bus tickets, and point-of-sale transactions (outbound). One cautions against a fragmented market with unhealthy competition that slows uptake with siloed solutions, and digging deeper, we see concern for regulation that limits "bank-FinTech collaboration" and "cross-sector partnerships".

The answers to the third research question, "What are the perceptions of subject-matter experts about the required framework conditions and success factors to develop new business models for money transfer or payment systems successfully in Africa?", reveal that the respondents view technology infrastructure, customers, and favourable regulation as key framework conditions for the new businesses (see Table 7), and this finding is consistent with our previous work (Ferguson \& Neubert, 2019). A deeper look at the responses also reveals that cooperation and collaboration (e.g., 


\section{Digital Payments: Impact Factors and Mass Adoption in Sub-Saharan Africa}

Leigh Soutter, Kenzie Ferguson, and Michael Neubert

Table 7. Selected quotations from interviewees in response to questions about framework conditions and success factors (Research Question 3)

\begin{tabular}{|c|c|}
\hline Category & Quotations (Examples) \\
\hline \multirow[t]{2}{*}{ Customer } & $\begin{array}{l}\text { - "Penetration of smartphone usage among potential customers (including low cost and } \\
\text { availability)" }\end{array}$ \\
\hline & $\begin{array}{l}\text { - The level of unbanked people and the number of unmet needs in the financial sector is probably } \\
\text { very appealing to new MPTS (mobile payment and transfer system) models as they would have a } \\
\text { large segment of potential clients to target which are not being currently served" }\end{array}$ \\
\hline \multirow[t]{4}{*}{ Technology } & - “Technology, physical infrastructure, and training required to provide Internet / phone access" \\
\hline & - "Communication infrastructure to connect with rural areas" \\
\hline & $\begin{array}{l}\text { - "Technological infrastructure (high-speed Internet access to allow instant peer-to-peer } \\
\text { payments" }\end{array}$ \\
\hline & $\begin{array}{l}\text { - "Cybersecurity should be as innovative as the new channels implemented to ensure a higher } \\
\text { protection to clients, the platform, and the suppliers" }\end{array}$ \\
\hline \multirow[t]{5}{*}{ Institutions } & • “Identity verification” \\
\hline & $\begin{array}{l}\text { - } \quad \text { "Regulation (smart regulation, consumer protection, privacy, provider must guarantee } \\
\text { payments)" }\end{array}$ \\
\hline & - "Experimental regulatory approach to new technologies, with a focus on customer protection" \\
\hline & • "Political and economic stability" \\
\hline & $\begin{array}{l}\text { - "A fragmented market with multiple players may hinder the path to the critical tipping point. If } \\
\text { there are too many players with closed systems, it will be difficult to reach the critical mass } \\
\text { required." }\end{array}$ \\
\hline \multirow[t]{4}{*}{$\begin{array}{l}\text { Collaborative / } \\
\text { synergistic effects }\end{array}$} & $\begin{array}{l}\text { - "Network effects: Inbound Payment Incentives (such as government payments, employer } \\
\text { payments, and the like)" }\end{array}$ \\
\hline & $\begin{array}{l}\text { - "Network incentives: Outbound Payment Incentives (such as points or discounts on taxes, bus } \\
\text { tickets, Uber, point-of-sale transactions, and other transactions)" }\end{array}$ \\
\hline & $\begin{array}{l}\text { - "Fintechs, telecommunication operators, financial institutions, and the government should work } \\
\text { together in a common ground" }\end{array}$ \\
\hline & - "Big data and cloud services help storage, analyze, and monitor the new services" \\
\hline
\end{tabular}

within and between leadership, institutions, and competitors) are important success factors. We found support in the literature, regulatory records, and industry reports for conclusions regarding technology infrastructure (Sy et al., 2019), customer base (Demirgüç-Kunt et al., 2018), regulation (Burns, 2018), and collaboration (Chironga et al., 2017). Christensen and co-authors (2019) contend that framework conditions evolve with technology adoption, and the opportunity size warrants dealing with lack of infrastructure and inefficient institutions and internalizing essential activities even if they are not core to the business. Indeed, a look at the case studies shows the regulatory stance of Kenya and Nigeria evolved over time, and in the case of Nigeria there are explicit calls for cooperation collaboration on interoperability and money agent networks.

\section{Discussion}

Framework

The findings presented above confirm our previous research, and in this section, we adopt a framework presented in Ferguson and Neubert (2019) to the lens of non-consumption described by Christensen and 


\title{
Digital Payments: Impact Factors and Mass Adoption in Sub-Saharan Africa
}

\author{
Leigh Soutter, Kenzie Ferguson, and Michael Neubert
}

co-authors (2019). Our framework in Figure 1 consists of three main factors that impact the adoption of digital money transfer and payment systems in Africa: 1) Customers, 2) Technology, and 3) Institutions. The solid black lines represent interactions and the dashed gray lines represent the flow of funds. Arrows in the figure point in both directions as the customer base, products, and supporting institutions interact and evolve together through customer adoption.

\section{Customer}

Our review of the literature and the expert responses shows that the primary customers for the new payment and money transfer systems generally spend cash and participate in the informal economy. The link from the entrenched product (cash) to the customer is a reminder that, in terms of Christensen and co-authors (2019), this is a classic market-creating opportunity that addresses a massive low-income customer base at low margin. In Figure 1, the black two-way connections between the Customers, Technology, and Adoption represent the customer focus that will be needed to generate demand and ultimately adoption (Theme 1). Understanding, teaching, and iterating with the customer in their environment will be central to innovating a product that solves the customer's "job to be done" in a way that breaks cost and usability barriers (Christensen et al., 2019).

\section{Technology}

Our research shows that the new digital money transfer and payment systems in sub-Saharan Africa should be based on readily available affordable mobile platforms (Theme 2) with front ends that radically simplify, lower the cost, and de-risk the sending and managing of money (Theme 3). As a group, the findings appear largely agnostic to the particular technologies "under

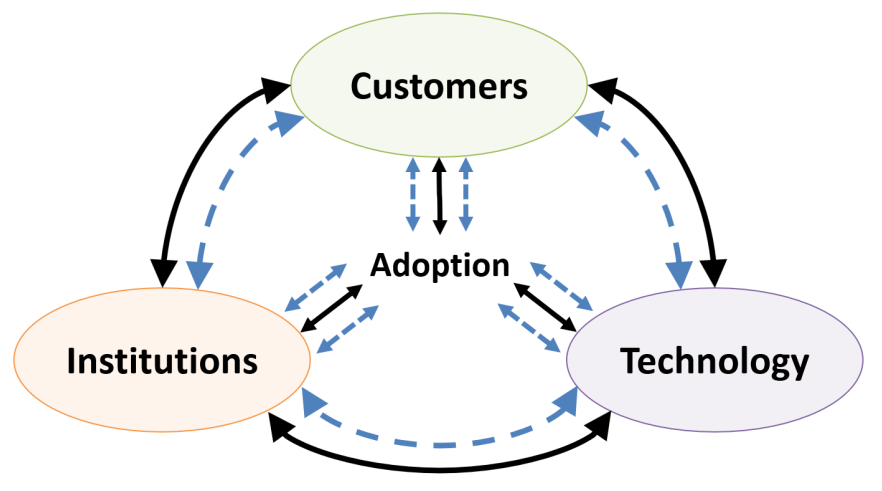

Figure 1. Framework of factors that affect FinTech adoption in sub-Saharan Africa the hood" except to underscore the need for improved technology infrastructure and the important roles of customer security, big data and analytics (e.g., features, regulation, and training). They also auger that blockchain and cryptocurrency innovations have great potential (i.e., to reconfigure the value chain, accomplish more, lower costs, and do this in a way that is invisible to the user), but see many uncertainties (e.g., regulation and transaction limits).

\section{Institutions}

Our experts include good technology infrastructure and regulation as necessary conditions for the success of the industry (Theme 5) but also allow that these may evolve with the market. The view that institutions and governance evolve with technology and market needs is consistent with the work of Christensen and co-authors (2019), who shows that market-creating innovations can "pull" enabling conditions into place; for example, they produce jobs to make, market, distribute, and sell the new products, and the profits flow as taxes to fund public missing services in society, government and regulators, education, infrastructure, and health care. Consider the M-Pesa ecosystem in Kenya. In Figure 2, the arrows to and from Institutions represent technology regulation, market regulation, and infrastructure spending (Technology). Likewise, there is regulation for customer protection and spending for supporting services (Customer). We also multiply the number of arrows to and from Adoption to represent momentum gains from collaboration and synergies as the customer base, the technology, and the institutional framework increasingly manifest an enabling environment (e.g., institutional evolution in Nigeria). In terms of our theoretical foundation, Christensen and co-authors point out that marketcreating innovations have fueled the institutional and economic emergence of many countries (e.g., the United States, Japan, and South Korea) and claim they can do the same for Africa (Christensen, 2017; Christensen et al., 2019).

\section{Comparison to our previous study}

In a previous study (Ferguson \& Neubert, 2019), we analyzed the same database through the lens of Gourville $(2005,2006)$ and presented a framework with three main impact factors that affect innovation adoption of digital payment systems in Africa: 1) Technology Innovation, 2) Regulation, and 3) Customer Demand. In the current study, which analyzes the data through the lens of Christensen and co-authors (2019), the impact factors we identify are: 1) Customers, 2) Technology, and 3) Institutions (Figure 2). In the previous interpretation (Ferguson \& Neubert, 2019), Demand and Innovation are 


\section{Digital Payments: Impact Factors and Mass Adoption in Sub-Saharan Africa}

Leigh Soutter, Kenzie Ferguson, and Michael Neubert

part of the framework conditions, but in the current interpretation (Figure 1) demand and innovation are evolutionary processes. In the current article, we also use the more generalized term Institutions as a catch-all for aspects of good governance (e.g., regulation, institutions, supporting infrastructure and services). More importantly, we mention the centre of our theoretical framework "Customer" first - the customers effectively co-design the product and, by "pulling" it into their lives, they bring about the necessary institutions to support the industry.

\section{Conclusions}

This article contributes to the body of research on FinTech services by looking into impact factors for the successful adoption of digital payment and money transfer systems in Africa through the lens of the theoretical framework by Christensen and co-authors (2019), who champion low-margin market-creating innovations that target non-consumption. We provide a framework of the impact factors (customers, technology, institutions) and their relationship to adoption that can be used by FinTech innovators and policymakers when considering opportunities in emerging markets. This work follows a previous study (Ferguson \& Neubert, 2019), which analyzes the same fundamental data through the lens of Gourville $(2005,2006)$.

In this article, we specifically identify the primary market for new money transfer and digital payment in Africa as non-consumers of formal financial services that are relatively new to technology. Our study shows that generating demand likely will involve stimulating awareness and educating customers. To create this market will require innovation that radically simplifies, lowers the cost, and de-risks money transfers, but the particulars of the technology are less important than the cost and usability.
The experts see a large customer base, technology infrastructure, and a favourable regulatory/institutional environment as pre-conditions for success, but they understand that these co-evolve as the market develops. This is supported by Christensen and co-authors (2019), who claim that institutional development is ineffective when top-down, and instead market-creating innovations trigger a "pull strategy" of institutional development that leads to prosperity. We point to the rapid adoption and growth of the mobile money under favourable framework conditions (Kenya) to show the potential for FinTech innovation on the continent. We also recognize that, on longer time frames, the co-evolution of technology, institutions, and demand are paving the way for renewed opportunities in Nigeria in particular and across Africa in general.

Our findings support the conclusion that mobile money is the foundation for the success of other digital money and transfer business models (EY, 2019). Further research, specifically quantitative research, is recommended to test the proposed framework. This article identified three additional areas for further study: FinTech adoption in individual markets because of the vast diversity within Africa; collaborations (e.g., cross-sector and pan-African), their regulation, and the growth of the industry; and FinTech innovations that accommodate the transfer of unbanked assets to the formal economy (e.g., unique identification, credit scoring, asset digitization, and registry).

We close by reminding the reader that the FinTech industry is positioned to enable sustainable growth in the economy of sub-Saharan Africa (EY Group, 2017) and holds the potential to improve the lives of hundreds of millions of citizens (Demirgüç-Kunt, 2018). 


\section{Digital Payments: Impact Factors and Mass Adoption in Sub-Saharan Africa}

\section{Leigh Soutter, Kenzie Ferguson, and Michael Neubert}

\section{About the Authors}

Leigh Soutter is a Vice President at Florence Venture Partners, an angel investment group in Silicon Valley that helps entrepreneurs start great businesses. She holds a PhD in GES Hydrogeology from Stanford University in the United States and has leveraged her experience with scientific computing as a technology consultant, entrepreneur, and investor. Dr. Soutter currently is working towards a second $\mathrm{PhD}$ at the International School of Management (ISM) in Paris where her dissertation research involves the role of innovative technologies in emerging markets.

Kenzie K. Ferguson is a recognized leader in corporate social responsibility (CSR). She built an awardwinning CSR department for a multinational S\&P 500 Company. Ms. Ferguson recently joined Delta Dental of California as their Vice President of Foundation and CSR. She is distinguished as an influencer with a growth mindset, creative problem-solving skills, and an ability to achieve goals with limited resources. Ms. Ferguson holds a Bachelor of Arts in Russian Studies from the University of California in the United States and an MBA from Nyenrode University in the Netherlands, and she is currently a $\mathrm{PhD}$ candidate at the International School of Management (ISM) in Paris.

Michael Neubert is a Professor at the International School of Management (ISM) in Paris, France, where he obtained his $\mathrm{PhD}$ and is now also Chair of the Strategic Management Committee. He teaches doctoral-level courses in FinTech, valuation and acquisition, and international finance, among other subjects. His research interests concern the valuation and the development of innovative high-tech startups from emerging markets. Michael is a member of the Academy of Management, and he is a partner of a private equity firm that invests in high-tech startups and supports them in the development of new foreign markets.

\section{References}

Alliance for Financial Inclusion. 2010. Case Study Enabling Mobile Money Transfer: The Central Bank of Kenya's Treatment of M-Pesa. Bangkok, Thailand: Alliance for Financial Inclusion.

Burns, S. 2018. M-Pesa and the 'Market-Led' Approach to Financial Inclusion. Economic Affairs, 38(3): 406-421. https://doi.org/10.1111/ecaf.12321

Central Bank of Nigeria. 2009. Regulatory Framework for Mobile Payments Services in Nigeria. Abaju, Nigeria: Central Bank of Nigeria.

Central Bank of Nigeria. 2015a. Guidelines on Mobile Money Services in Africa. Abaju, Nigeria: Central Bank of Nigeria.

Central Bank of Nigeria. 2015b. Regulatory Framework for Mobile Money Services in Nigeria. Abaju, Nigeria: Central Bank of Nigeria.

Central Bank of Nigeria. 2018a. Guidelines for Licensing and Regulation of Payment Service Banks in Nigeria. Abaju, Nigeria: Central Bank of Nigeria.

Central Bank of Nigeria. 2018b. Framework for Operation of the Shared Agent Network Expansion Facility (SANEF). Abaju, Nigeria: Central Bank of Nigeria.

Chironga, M., De Grandis, H., \& Zouaoui, Y. 2017. Mobile Financial Services in Africa: Winning the Battle for the Customer. New York: McKinsey \& Company.

Christensen, C. M. 1997. The Innovator's Dilemma: When New Technologies Cause Great Firms to Fail. Boston, MA: Harvard Business School Press.

Christensen, C. M., Ojomo, E., \& Dillon, K. 2019. The Prosperity Paradox. New York: Harper Business.

Demirgüç-Kunt, A., Klapper, L., Singer, D., Ansar, S., \& Hess, J. 2018. The Global Findex Database 2017: Measuring Financial Inclusion and the Fintech Revolution. World Bank. Accessed 1 May 2019: http://www.worldbank.org/globalfindex

EY Global. 2019. FinTechs in Sub-Saharan Africa: An Overview of Market Developments and Investment Opportunities. London: EY.

Ferguson, K. K., \& Neubert, M. 2019. Digital Payments: How New Technologies Disrupt Money Transfer Systems in Africa. In O. Dvouletý, M. Lukeš, \& J. Mísař (Eds.), Proceedings of the 7th International Conference Innovation Management, Entrepreneurship and Sustainability (IMES 2019): 195-207. Prague: Oeconomica Publishing House. https://doi.org/10.18267/pr.2019.dvo.2316.0

FinMark Trust. 2017. Research Report on Mobile Money in South Africa. Johannesburg, South Africa: FinMark Trust.

Gomber, P., Koch, J., \& Siering, M. 2017. Digital Finance and FinTech: Current Research and Future Research Directions. Journal of Business Economics, 87(5): 537-580. https://doi.org/10.1007/s11573-017-0852-X

Gourville, J. T. 2006. Eager Sellers \& Stony Buyers. Harvard Business Review, 84(6): 98-106.

Gourville, J. T. 2005. The Curse of Innovation: A Theory of Why Innovative New Products Fail in the Marketplace. HBS Marketing Research Paper No. 05-06. Boston, MA: Harvard Business School. http://dx.doi.org/10.2139/ssrn.777644 


\section{Digital Payments: Impact Factors and Mass Adoption in Sub-Saharan Africa}

\section{Leigh Soutter, Kenzie Ferguson, and Michael Neubert}

GSMA. 2018a. 2017 State of the Industry Report on Mobile Money. London: GMSA.

https://www.gsma.com/mobilefordevelopment/resources/2017-

state-industry-report-mobile-money/

GSMA. 2018b. The Mobile Economy Sub-Saharan Africa 2018. London: GMSA.

https://www.gsma.com/r/mobileeconomy/sub-saharan-africa/

GSMA. 2019. Markets. GSMA Intelligence. Accessed June 1, 2019: http://gsmaintelligence.com/markets/

IIAG. 2018. Ibrahim Index of African Governance (IIAG). Mo Ibrahim Foundation. Accessed June 1, 2019: http://mo.ibrahim.foundation/iiag/

IMF. 2019. Access to Macroeconomic \& Financial Data. International Monetary Fund (IMF). Accessed June 1, 2019: http://data.imf.org/?sk=388DFA60-1D26-4ADE-B505A05A558D9A42\&sId=1479331931186

Juma, J., \& Wasunna, N. 2018. Distribution 2.0: The Future of Mobile Money Agent Distribution Networks. London: GMSA. https://www.gsma.com/mobilefordevelopment/wpcontent/uploads/2018/07/Distribution-2.0-The-future-of-mobilemoney-agent-distribution-networks.pdf

Lepoutre, J., \& Oguntoye, A. 2018. The (Non-) Emergence of Mobile Money Systems in Sub-Saharan Africa: A Comparative Multilevel Perspective of Kenya and Nigeria. Technological Forecasting and Social Change, 131: 262-275.

https://doi.org/10.1016/j.techfore.2017.11.010

Medina, L., Jonelis, A., \& Cangul, M. 2017. The Informal Economy and Sub-Saharan Africa: Size and Determinants. Working Paper 17/156. Washington, DC: International Monetary Fund (IMF).

Naboulsi, N., \& Neubert, M. 2018. Impact of Digital Currencies on Economic Development in Kenya. In Proceedings of the ACBSP Region 8 Fall Conference 2018: 368-387.

Neubert, M. 2017. Lean Internationalization: How to Globalize Early and Fast in a Small Economy. Technology Innovation Management Review, 7(5): 16-22. http://doi.org/ 10.22215/timreview/1073

Neubert, M. 2018. The Impact of Digitalization on the Speed of Internationalization of Lean Global Startups. Technology Innovation Management Review, 8(5): 44-54.

http://doi.org/10.22215/timreview/1158
Neubert, M. 2019. Funding Innovations for Sustainable Growth in Emerging Markets. International Journal of Economics and Finance, 11(4): 16-24. https://doi.org/10.5539/ijef.v11n4p16

Neubert, M., \& Van der Krogt, A. 2018. Impact of Business Intelligence Solutions on Export Performance of Software Firms in Emerging Economies. Technology Innovation Management Review, 8(9): 39-49.

http://doi.org/10.22215/timreview/1185.

Quartz Africa. 2018. MTN Is Planning to Launch Its Mobile Money Service in Nigeria Next Year. Quartz Africa, November 14, 2018. Accessed June 1, 2019: https://qz.com/africa/1462453/mtn-to-launch-mobile-money-innigeria-with-central-bank-okay/

Realini, C., \& Mehta, K. 2015. Financial Inclusion at the Bottom of the Pyramid. Victoria, BC: Friesen Press.

Simanis, E., \& Duke, D. 2014. Profits at the Bottom of the Pyramid: A Tool for Assessing Your Opportunities. Harvard Business Review, 92(10): 82-93.

Sun, I. Y. 2017. The Next Factory of the World: How Chinese Investment is Reshaping Africa. Boston, MA: Harvard Business Review Press.

Sy, A. N., Maino, R., Massara, A., Perez Saiz, H., \& Sharma, P. 2019. FinTech in Sub-Saharan Africa. Departmental Paper No. 19/04. Washington, DC: International Monetary Fund (IMF).

USAID. 2018. The Digital Financial Services Landscape in Nigeria: Enabling Market Conditions for Pay-As-You-Go Solar. Washington, DC: U. S. Agency for International Development (USAID). https://www.usaid.gov/sites/default/files/documents/1860/Enabli ng_Market_Conditions_for_Pay-As-YouGo_Solar_Executive_Summary.pdf

World Bank. 2019a. Population, Total. World Bank Group. Accessed June 1, 2019: https://data.worldbank.org/indicator/SP.POP.TOTL

World Bank. 2019b. Poverty Headcount Ratio at $\$ 1.90$ a Day. World Bank Group. Accessed June 1, 2019: https://data.worldbank.org/indicator/SI.POV.DDAY

Yin, R. K. 2017. Case Study Research and Applications: Design and Methods. Thousand Oaks, CA: SAGE Publications.

Citation: Soutter, L., Ferguson, K., \& Neubert, M. 2019. Digital Payments: Impact Factors and Mass Adoption in Sub-Saharan Africa. Technology Innovation Management Review, 9(7): 41-55. http://doi.org/10.22215/timreview/1254

Keywords: FinTech, mobile money, payments, blockchain, sub-Saharan Africa, non-consumption, adoption 


\section{Academic Affiliations and Funding Acknowledgements}
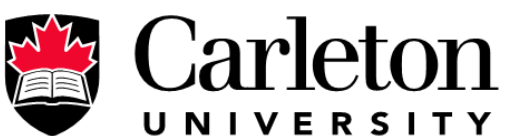

U N I V E R S I T Y

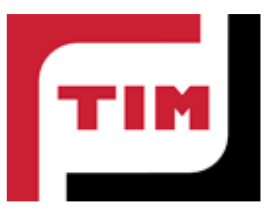

Technology Innovation Management (TIM; timprogram.ca) is an international master's level program at Carleton University in Ottawa, Canada. It leads to a Master of Applied Science (M.A.Sc.) degree, a Master of Engineering (M.Eng.) degree, or a Master of Entrepreneurship (M.Ent.) degree. The objective of this program is to train aspiring entrepreneurs on creating wealth at the early stages of company or opportunity lifecycles.

- The TIM Review is published in association with and receives partial funding from the TIM program. 